\title{
MORPHOLOGICAL, PHYSICAL, AND CHEMICAL CHARACTERISTICS OF SOME VOLCANIC SOILS OF MT. GALUNGGUNG
}

\author{
Budi Mulyanto \\ Laboratory of Soil Genesis, Classification and Mineralogy, \\ Department of Soil Sciences, Faculty of Agriculture, Bogor Agricultural University \\ Jl. Raya Pajajaran 1, Bogor 16144
}

\begin{abstract}
Results of study on morphological, physical, and chemical characteristics of three pedons developed on volcanic materials of Mt. Galunggung, namely BM1, BM2, and BM3, showed that these pedons had a different stage of profile development. Pedon BM1 is classified as undeveloped, BM2 is medium developed, and BM3 is strongly developed. This is mainly caused by differences in relative age of the parent rocks, and elevation. Although classified as undeveloped, the soil represented by pedon BM1, the youngest, has immediately been used by farmers for rice cultivation because of water abundance, and high availability of $P$, and basic cations derived from weathering of easily weathered amorphous materials and minerals. According to the Soil Taxonomy system of the USDA (Soil Survey Staff, 1996), pedons BM1, BM2, and BM3 are classified as Typic Udipsamment, Taptho Hapludandic Typic Troporthent, and Humic Hapludult, respectively. Whilst, according to FAO/UNESCO system (1988), these pedons are classified as Eutric Regosol, Eutric Regosol and Humic Alisol, respectively.
\end{abstract}

Keywords: profile development, soil characteristics, volcanic soils.

\section{INTRODUCTION}

Soils developed on volcanic materials usually have distinctive properties which in many parts of the world are reflected in extremely high crops productivity, sometimes significantly associated with some of the world's highest human carrying capacity (Leamy, 1984), such as those developed in Java Island (Sutanto, 1988). The most important diagnostic features of volcanic ash derived soils include variation in chemical composition, specific morphologic features and the presence of some specific minerals such as short range onder minerals, i.e. allophane, imogolite and some oxides (De Coninck, 1990).

According to FAO/UNESCO (1974), volcanic materials constitute the parent material of many different soils. Volcanic material derived soils have been classified in many countries: as Andosols, Regosols, and Latosols in Indonesia (Pusat Penelitian Tanah, 1976); Allophane soils and Kuroboku soils in Japan; Alluvial or Yellowish
Brown Loam in New Zealand; as Andosols by FAO/UNESCO (1974) and Andisol by Soil Survey Staff (1996).

In Indonesia, a group of soils derived from volcanic materials is widely spread over the archipelago, from Sumatera in the west over Java to Lesser Sunda Islands in the east (Tan, 1965), and covers about $\mathbf{2 0}$ millions hectares or about $10.4 \%$ of the total land area (Pusat Penelitian Tanah, 1976). Most of food crops production in Indonesia are derived from these soils. Unfortunately, documentation or studies on these very important soils are very rare.

Study on genesis and morphology of volcanic ash derived soils in Indonesia was started by Dudal and Soepraptohardjo (1957). In addition, study on physico-chemical properties was carried out by Tan $(1959,1965)$, Tan and Van Schuylenborgh (1959), and Hardjosoesastro et al. (1983). The most recent and comprehensive studies were conducted by Sutanto (1988) and Mulyanto (1990). 
This paper presents results of study on morphological, physical, and chemical properties of different volcanic materials derived soils of Galunggung Volcano in West Java and their classification.

\section{PHYSICAL ENVIRONMENT}

Some physical environmental factors strongly determine characteristics of a soil. The most important factors are geology, topography, climate and landuse. The geological factors are related to the properties of parent materials. Topographic position of the soil is related to the water regimes, which influence the weathering processes, and physical and chemical properties. The climate and landuse also determine the weathering processes.

\section{Geology}

Mt. Galunggung is located at about $7^{\circ} 15^{\prime}$ South Latitude and $108^{\circ} 03^{\prime}$ East Longitude which covering an area in part of Garut and Tasikmalaya districts, West Java. The eruption activities of this volcano were reported in 1822,1894, 1918, and 1982 (Escher, 1920; Bronto, 1982). From these eruptions, young deposits were built on the ruin of old deposits from eruptions before 1822.

Rocks found in surrounding Mt. Galunggung consist of lava, pyroclastic deposits, and thallus which can be divided into 11 rock units as follows: (1) Lahar deposits (QLh1), (2) Galunggung lava (QG1), (3). Beuticanar lava (QB1), (4) Galunggung pyroclastic deposits (QGjp), (5) Volcanic sliding deposits (QGIv), (6) Galunggung stream pyroclastic deposits (QGap), (7) Lahar 2 deposits (Q/h2), (8). Walirang lava (QWI), (9) Lahar 3 deposits (Qlh3), (10) Jadi lava (QJI), and (11) Thallus (Qta) (Fig. 1).

\section{Climate}

The climate of Java is significantly characterised by a distinct wet and dry seasons. This season type is well pronounced in East and Central Java and less pronounced in West Java (Table 1).

Rainfall almost occurs over the whole year. Minimum rainfall coincides with the monsoon months, that are in June, July and August. The annual rainfall is higher than $3.000 \mathrm{~mm}$. The average annual temperature is generally $24.5^{\circ} \mathrm{C}$ and the temperature is fairly uniform during the whole year with a variation that never exceeds $2^{\circ} \mathrm{C}$. Generally speaking, the mean monthly relative humidity does not vary greatly and is always higher than $80 \%$ due to high rainfall. The highest peak values of potential evapotranspiration is found in March and the lowest one in July.

According to Soil Taxonomy (1996), the investigated soils have udic moisture regime and isohyperthermic temperature regime.

\section{Vegetation and land use}

Not much of original vegetation is left in this area. They are mostly found on the top of volcanoes and mountains as protection forest areas. Areas unsuitable for agriculture are used for production forest of Swietenia macrophylla, Pinus merkusii, and Albizia falcataria or used as reforestation and agroforestry areas. The landuse for farming of the study area is mostly imigated rice field, particularly on the northem and eastem footslope. Since there exist no limitation of water, the cropping pattern varies from continuous rice (3x with short age cultivar or $2 x$ rice of medium age cultivar) to $1 x$ rice and secondary crops or another pattern depending on the market demand. In area where irrigation is not possible, rainfed agriculture is the dominant land use type with a great variety of crops planted in various combinations.

\section{MATERIALS AND METHODS}

\section{Material}

The three selected pedons are located in locations near Singaparna, Sukajadi and Indihiang of the Mt. Galunggung area, Tasikmalaya, West Java (Figure 2). They were selected on the basis of the Soil Map of West Java, at scale of 1:250 000 prepared by Pusat Penelitian Tanah (1976).

Soil samples were taken from every identifiable horizon of the selected pedons. Two kinds of soil samples were collected: bulk samples for routine physico-chemical analysis and undisturbed soil samples for physical analysis.

\section{Methods}

The routine physico-chemical analysis was carried out mainly according to the methods described in "Procedure for Soil Survey" (1984) except for granulometric analysis. All data were reported on the basis of the $<2 \mathrm{~mm}$ material. 
This paper presents results of study on morphological, physical, and chemical properties of different volcanic materials derived soils of Galunggung Volcano in West Java and their classification.

\section{PHYSICAL ENVIRONMENT}

Some physical environmental factors strongly determine characteristics of a soil. The most important factors are geology, topography, climate and landuse. The geological factors are related to the properties of parent materials. Topographic position of the soil is related to the water regimes, which influence the weathering processes, and physical and chemical properties. The climate and landuse also determine the weathering processes.

\section{Geology}

Mt. Galunggung is located at about $7^{\circ} 15^{\prime}$ South Latitude and $108^{\circ} 03^{\prime}$ East Longitude which covering an area in part of Garut and Tasikmalaya districts, West Java. The eruption activities of this volcano were reported in 1822, 1894, 1918, and 1982 (Escher, 1920; Bronto, 1982). From these eruptions, young deposits were built on the ruin of old deposits from eruptions before 1822 .

Rocks found in surrounding Mt. Galunggung consist of lava, pyroclastic deposits, and thallus which can be divided into 11 rock units as follows: (1) Lahar deposits (QLh1), (2) Galunggung lava (QG1), (3). Beuticanar lava (QB1), (4) Galunggung pyroclastic deposits (QGjp), (5) Volcanic sliding deposits (QGIV), (6) Galunggung stream pyroclastic deposits (QGap), (7) Lahar 2 deposits (Q/h2), (8). Walirang lava (QWI), (9) Lahar 3 deposits (Qlh3), (10) Jadi lava (QJ)), and (11) Thallus (Qta) (Fig. 1).

\section{Climate}

The climate of Java is significantly characterised by a distinct wet and dry seasons. This season type is well pronounced in East and Central Java and less pronounced in West Java (Table 1).

Rainfall almost occurs over the whole year. Minimum rainfall coincides with the monsoon months, that are in June, July and August. The annual rainfall is higher than $3.000 \mathrm{~mm}$. The average annual temperature is generally $24.5^{\circ} \mathrm{C}$ and the temperature is fairly uniform during the whole year with a variation that never exceeds $2^{\circ} \mathrm{C}$. Generally speaking, the mean monthly relative humidity does not vary greatly and is always higher than $80 \%$ due to high rainfall. The highest peak values of potential evapotranspiration is found in March and the lowest one in July.

According to Soil Taxonomy (1996), the investigated soils have udic moisture regime and isohyperthermic temperature regime.

\section{Vegetation and land use}

Not much of original vegetation is left in this area. They are mostly found on the top of volcanoes and mountains as protection forest areas. Areas unsuitable for agriculture are used for production forest of Swietenia macrophylla, Pinus merkusii, and Albizia falcataria or used as reforestation and agroforestry areas. The landuse for farming of the study area is mostly irrigated rice field, particularly on the northem and eastem footslope. Since there exist no limitation of water, the cropping pattern varies from continuous rice (3x with short age cultivar or $2 x$ rice of medium age cultivar) to $1 x$ rice and secondary crops or another pattem depending on the market demand. In area where irrigation is not possible, rainfed agriculture is the dominant land use type with a great variety of crops planted in various combinations.

\section{MATERIALS AND METHODS}

\section{Material}

The three selected pedons are located in locations near Singaparna, Sukajadi and Indihiang of the Mt. Galunggung area, Tasikmalaya, West Java (Figure 2). They were selected on the basis of the Soil Map of West Java, at scale of 1:250 000 prepared by Pusat Penelitian Tanah (1976).

Soil samples were taken from every identifiable horizon of the selected pedons. Two kinds of soil samples were collected: bulk samples for routine physico-chemical analysis and undisturbed soil samples for physical analysis.

\section{Methods}

The routine physico-chemical analysis was carried out mainly according to the methods described in "Procedure for Soil Survey" (1984) except for granulometric analysis. All data were reported on the basis of the $<2 \mathrm{~mm}$ material. 


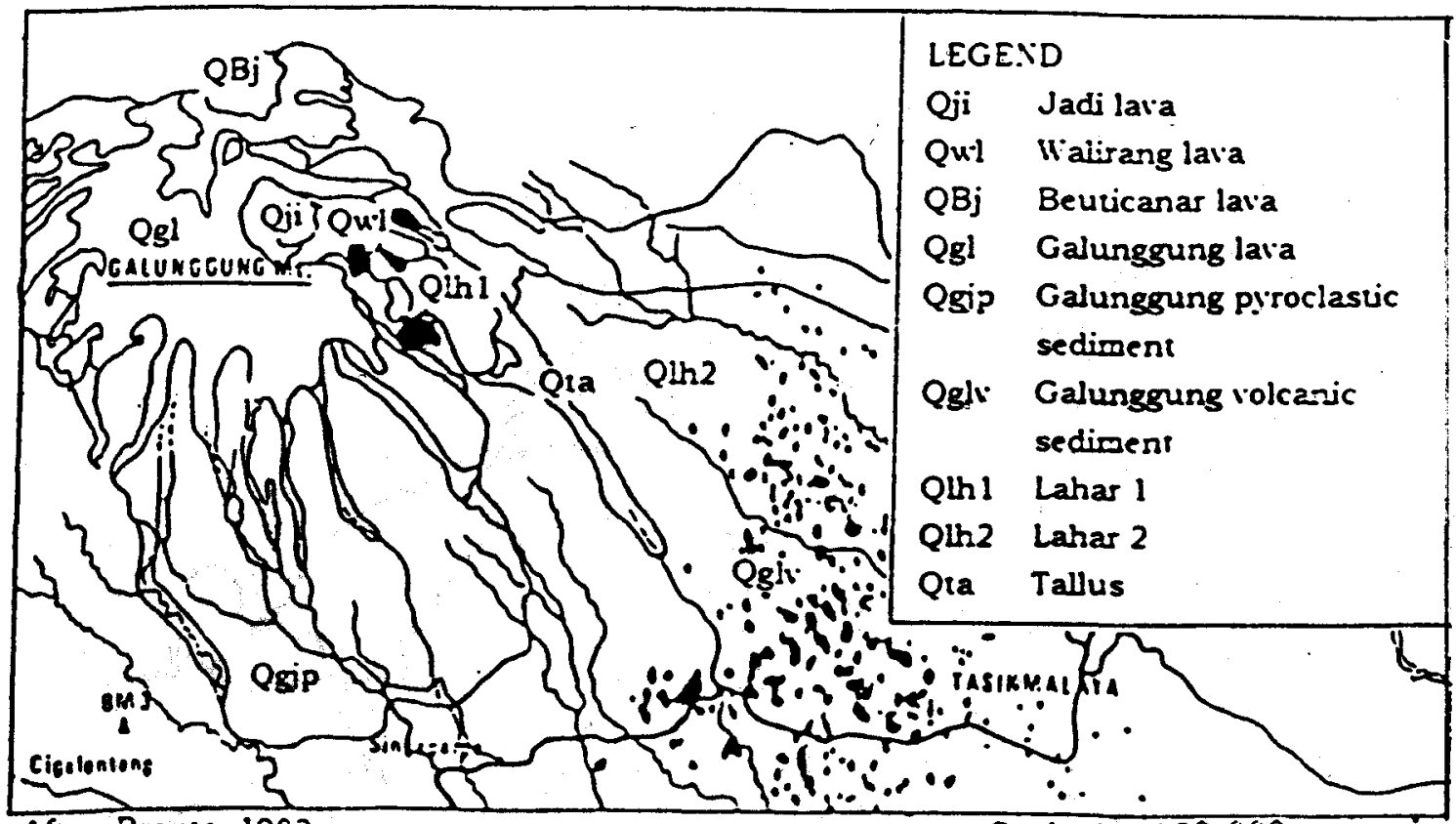

Afier: Brorio. 1982

Scale 1: 150000

Figure 1. Geology of the studied area

Table 1. Climatic Data of Tasikmalaya, West Java

\begin{tabular}{|c|c|c|c|c|c|c|c|c|c|c|c|c|c|}
\hline \multirow{2}{*}{$\begin{array}{l}\text { Climatic } \\
\text { Factors }\end{array}$} & \multicolumn{12}{|c|}{ Month } & \multirow[b]{2}{*}{ Annual } \\
\hline & $J$ & $\bar{F}$ & $\bar{M}$ & $\bar{A}$ & $\bar{M}$ & $\mathrm{~J}$ & $J$ & A & $s$ & 0 & $\bar{N}$ & $D$ & \\
\hline $\begin{array}{l}\text { Temp. }{ }^{\circ C} \\
\text { RH \%" } \\
\text { Rainfall } \\
\text { PET* }\end{array}$ & $\begin{array}{r}24.6 \\
86.0 \\
368.0 \\
130.2\end{array}$ & $\begin{array}{r}24.6 \\
85.0 \\
386.0 \\
122.1\end{array}$ & $\begin{array}{r}24.9 \\
86.0 \\
280.0 \\
135.5\end{array}$ & $\begin{array}{r}24.8 \\
85.0 \\
258.0 \\
128.1\end{array}$ & $\begin{array}{r}24.7 \\
86.0 \\
315.0 \\
111.3 \\
\end{array}$ & \begin{tabular}{r|}
23.9 \\
85.0 \\
160.0 \\
104.1 \\
\end{tabular} & $\begin{array}{l}18.7 \\
85.0 \\
82.0 \\
91.5\end{array}$ & $\begin{array}{r}23.7 \\
83.0 \\
103.0 \\
119.0\end{array}$ & $\begin{array}{r}23.8 \\
84.0 \\
213.0 \\
118.8\end{array}$ & $\begin{array}{r}24.5 \\
84.0 \\
395.0 \\
127.7\end{array}$ & $\begin{array}{r}24.8 \\
85.0 \\
337.0 \\
127.8\end{array}$ & $\begin{array}{r}24.8 \\
85.0 \\
236.0 \\
131.1\end{array}$ & $\begin{array}{r}24.0 \\
84.9 \\
3237.0 \\
1447.2\end{array}$ \\
\hline
\end{tabular}

Relative Hunidity

* Potential Evapo-Transpiration

The granulometric analysis was carried out by sieving and sedimentation. The particle size distribution of fraction $<2 \mathrm{~mm}$ analysis was done with $\mathrm{H}_{2} \mathrm{O}_{2}, 30 \%$ to remove organic matter by successive sedimentation after treatment. The sand fraction was separated by wet sieving using a $50 \mu \mathrm{m}$ sieve. Separation of clay and silt was carried out by successive sedimentation. The clay was siphoned and collected after 8 hours and 35 minutes from the suspension from $10 \mathrm{~cm}$ depth. The percentage was calculated on the dry weight basis, following the size classes of USDA and textural classes according to intemational classification (Soll Survey Staff, 1996).

\section{RESULT AND DISCUSSION}

All pedons are derived from quatemary deposits have developed on the complex of Galunggung volcanoes: BM1 on the Qta unit, BM2 and BM3 on the QGjp and Qlh2 unit.

Stratigraphically, the Qta unit is the youngest, since it was due to the eruption of 1982 . The pedons BM1 and BM2 are situated above $500 \mathrm{~m}$ ast, BM3 below $500 \mathrm{~m}$ asl. The footslopes of volcanoes have been dissected, giving rise to a gently to rolling landscape at lower altitude, passing over into rolling and hilly at higher altitude. 


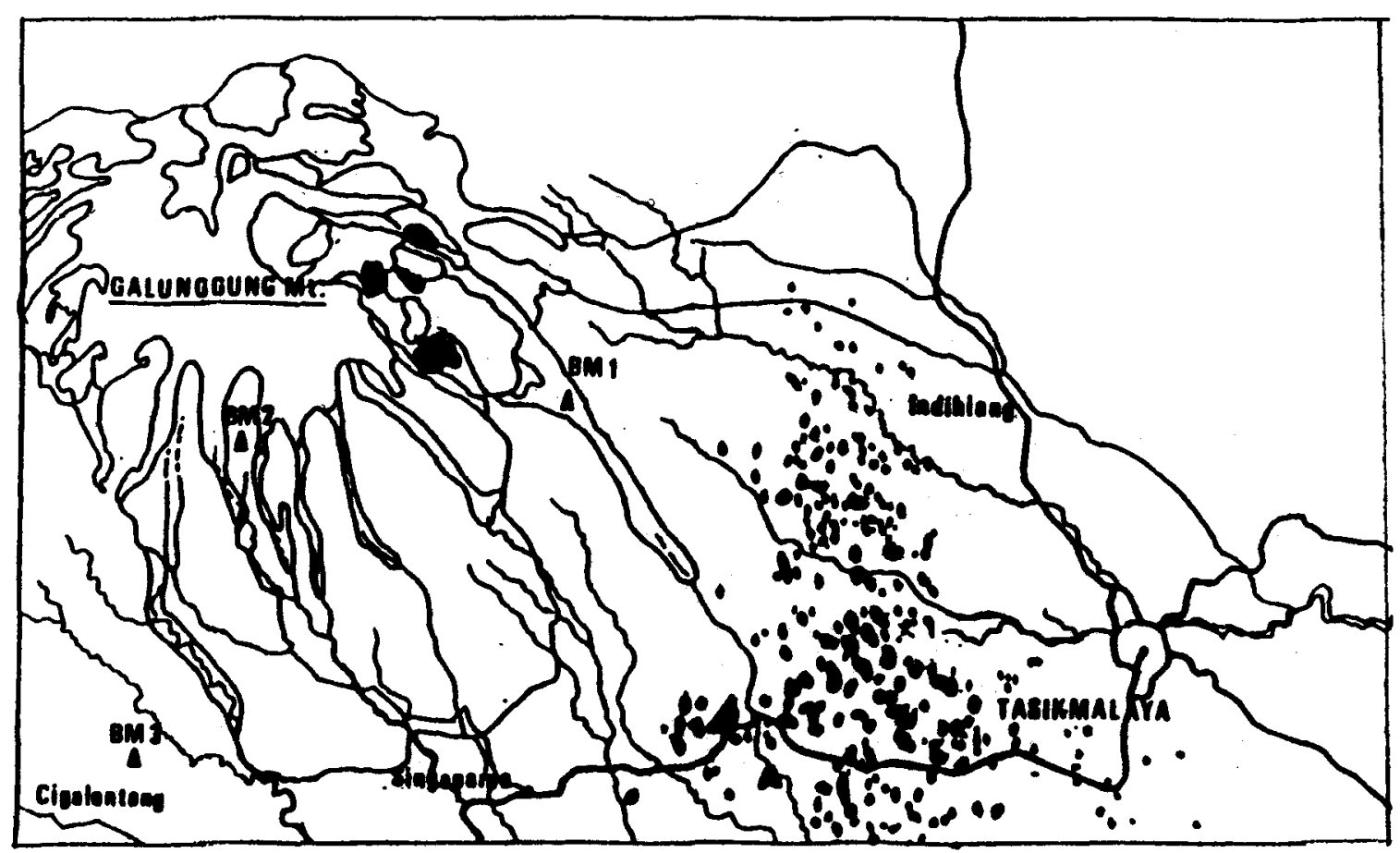

Figure 2. The location of soil profiles

The recent soil on Qta is a Grey Regosol (BM1). On the older deposits situated at higher altitude the soil is Andosol (BM2) while profile BM3 on the oldest deposit and at lower altitude forms a Reddish Brown Latosol. Due to repeated eruptions and sedimentation, the pedons display a composite morphology and several buried soils may be present underneath the present day profiles. Various types of land utilisation are recognised in these areas: gently sloping to level terrain have been transformed into imigated rice field while the undulating to rolling land is used for dry land agriculture. The hilly to mountainous terrain are mostly for agroforestry.

\section{Morphological properties}

Pedon BM1 is located on a recent volcanic alluvial plain at the eastem footslope of Galunggung, about $550 \mathrm{~m}$ asl. The terrain is level, without evidence of erosion. The profile has no horizon differentiation, sandy, massive and structurless, firm, and no root development.
These sandy soils are mined for building construction and afterwards they are transformed into paddy rice fields.

Pedon BM2, located in Kampung Sukajadi Linggawangi, Leuwisari district, Tasikmalaya is situated in hilly terrain on the southem convex slope of Mt. Galunggung, at about $750 \mathrm{~m}$ asl.. The upper layers I to IV are recent and have little or no development. Layer $V$ is an older soil. The soil is mostly sand to sandy loam, altemating massive and loose structureless in the layers I to IV, but layer $V$ is weak, fine subangular blocky, very friable and firm consistence in the range of very dark brown to dark yellowish brown.

This area is dominated by dryland agriculture. Terracing and mixed farming are applied without fertilization.

Pedon BM3, located in Cigalontang village, Tasikmalaya is observed on the middle slope of a hill on the Southem lower footslope of Mt. Galunggung. The evidence of erosion is 
moderate. This soil is relatively deep and well drained.

The colour changes from dark grey brown in the $A$ horizon through reddish brown in the $E$ and $B t 1$ horizons to strong brown in the Bt2 and the Bt3 horizons. The texture is clay throughout, and very weak patchy cutans are noticed in the Bt2 and Bt3 horizons. The structure is moderate-medium granular in the A horizon, gradually changes into weak medium subangular blocky in the $E, B t 1$ and Bt2 horizons, and to moderate medium subangular blocky in the Bt3 horizon. The consistence in moist condition is friable in the $A$, $E$, and $B t 1$ horizons and gradually changes to firm and very firm in the Bt2 and Bt3 horizons. The material is plastic to very plastic. Root development is up to $90 \mathrm{~cm}$ depth. The land utilisation is mostly agroforestry. Paddy rice field is found only where water is available.

\section{Physical and Chemical Properties}

The physical and chemical analysis data are presented in Table 2. and Table 3.

The samples of the young volcanic soil (BM1) disperse in alkali solution. The particle size distribution is dominated by sand fraction. Textural class of the horizons ranges from sand to loamy sand. The bulk density has not been determined. The soil reaction is acid in $\mathrm{H}_{2} \mathrm{O}$ and $\mathrm{pH} \mathrm{KCl}$ is $0.6-$ 1.1 units lower than the $\mathrm{pHH}_{2} \mathrm{O}$. These feature has been assumed to express a net negative charge of the exchange complex throughout the profile (Tan, 1982). The organic carbon content seems very low (0.11-0.88\%) and shows an irregular distribution with depth. The low content of nitrogen is related to the low content of organic matter. The high amount of available $P$ is a result of weathering of volcanic glass and fluoroapatite microcrystals which normally occurs as an accessory mineral or as an inclusion of ironbearing minerals in all types of eruptive rocks (Prinz et. al., 1978). The CEC of this soil is very low because it has a very small colloidal fraction. Amounts of cations extracted with $\mathrm{NH}_{4} \mathrm{OAc}$ are high, giving saturation of $100 \%$ or more, indicating that part of the cations are present as free salts. Since qualitative testing shows the presence of $\mathrm{SO}_{4}{ }^{=}$, they are probably present as sulphates.

The layers I to IV of profile BM2 show a no clear evolution and the buried soil behave in a different way. The samples of the upper layers disperse with normal dispersing agent whereas the buried one seems to disperse in acid conditions. The texture is dominated by sand: $73.62-95.74 \%$ in the upper layers and $58.94-63.97 \%$ in the buried soil. The bulk density is high in the upper layers but about 0.9 in the buried one. Organic carton $(0.15-2.7 \%)$ and nitrogen $(0.02 \%)$ are very low. The available $P$ is medium $(0.3-9.2 \mathrm{ppm})$. The $\mathrm{NH}_{4} \mathrm{OAC}$ CEC is low $(5.60-11.80 \mathrm{me} / 100 \mathrm{~g})$ and the sum of exchangeable cations ranges from 1.99 to $9.59 \mathrm{me} / 100 \mathrm{~g}$ giving a base saturation between 35 and $88 \%$. The buried soil has different characteristics, with organic carbon between 3.29 and $3.75 \%$ and $N$ ranging from 0.26 to $0.27 \%$. The available $P$ is not significant. CEC $\mathrm{NH}_{4} \mathrm{OAC}$ is relatively high (26.73-32.30 me/ $100 \mathrm{gr}$ ) and the sum of extractable cations (1.18-4.73 \%) and base saturation are low (4.41. $14.64 \%)$. The samples of the old volcanic soil (BM3) disperse with normal dispersing agent and particle size distribution is dominated by the clay fraction ranging between 50.01 to $88.28 \%$. The clay content increases with depth. Bulk density is higher than $0.9 \mathrm{~g} / \mathrm{cc}$.

The $\mathrm{pH} \mathrm{H}_{2} \mathrm{O}$ is acid, ranging from 5.0 to 5.7. The $\mathrm{pH} \mathrm{KCl}$ is lower than $\mathrm{pH} \mathrm{H}_{2} \mathrm{O}$ with a difference in the range of 1.2 to 1.4 units. Organic carbon content decreases with depth and ranges from 0.25 to $2.29 \%$. The total- $\mathrm{N}$ is low $(0.4-0.14 \%)$ and the available-P is mostly not significant. The sum of cations is relatively high $\mathbf{7 . 2 8 - 1 0 . 3 6}$ $\mathrm{me} / 100 \mathrm{~g}$ ) and is dominated by calcium, while the $\mathrm{NH}_{4} \mathrm{Oac}$ CEC $\mathrm{pH} 7$ is medium (22.84 to 26.96 $\mathrm{me} / 100 \mathrm{~g})$. Therefore, the base saturation is also medium $(30.01-45.36 \%)$.

\section{Soil Classification}

Pedon BM1 (Grey Regosols). The soil has an ochric epipedon, with $<35 \%(V)$ of rock fragments and sand texture. The soil moisture regime is udic and the soil temperature regime is isohyperthermic. Base saturation is $100 \%$. This soil is classified as Typic Udipsamment, sandy, isohyperthemic (Soil survey staff, 1996) or as Eutric Regosol (FAO/UNESCO, 1988).

Pedon BM2 (Yellowish Brown Andosols). The soil has an ochric epipedon, < $35 \%$ rock fragments and sand to sandy loam texture. The profile can be divided into two parts, the upper part is a soil without profile development and the buried part is soil with andic properties. The base saturation is higher than $50 \%$ in the upper soil but less than $50 \%$ in the buried soil. This soil is classified as Taptho Hapludandic Typic Troporthents, sandy loam, isohyperthermic (Soil Survey Staff, 1996), or as Eutric Regosol (FAONNESCO, 1988). 
Table 2. Physical Analytical Data

\begin{tabular}{|c|c|c|c|c|c|c|c|}
\hline \multirow[t]{2}{*}{ Pedon } & \multirow[t]{2}{*}{ Horizon } & \multirow[t]{2}{*}{ Depth } & \multicolumn{3}{|c|}{ Particle Size } & \multirow{2}{*}{$\begin{array}{l}\text { Texture } \\
\text { Classes }\end{array}$} & \multirow{2}{*}{$\begin{array}{c}\mathrm{BD} \\
(\mathrm{gr} / \mathrm{CC})\end{array}$} \\
\hline & & & Sand & Silt & Clay & & \\
\hline BM1 & $\begin{array}{l}\text { I } \\
\text { II } \\
\text { III } \\
\text { IV }\end{array}$ & $\begin{array}{l}0-45 \\
45-85 \\
85-120 \\
>120\end{array}$ & $\begin{array}{l}91.83 \\
88.94 \\
84.91 \\
91.35\end{array}$ & $\begin{array}{c}\ldots \% \ldots \ldots \\
3.93 \\
5.43 \\
12.77 \\
4.22\end{array}$ & $\begin{array}{l}4.25 \\
5.63 \\
2.42 \\
4.43\end{array}$ & $\begin{array}{l}\text { sand } \\
\text { sand } \\
\text { loamy sand } \\
\text { sand }\end{array}$ & $\begin{array}{l}- \\
- \\
-\end{array}$ \\
\hline BM2 & $\begin{array}{l}\text { I } \\
\text { II } \\
\text { III } \\
\text { IV } \\
\text { VA } \\
\text { VAB } \\
\text { VC }\end{array}$ & $\begin{array}{l}0-20 \\
20-28 \\
28-33 \\
33-38 \\
38-65 \\
65-90 \\
90-130\end{array}$ & $\begin{array}{l}91.35 \\
73.62 \\
95.74 \\
79.24 \\
63.57 \\
63.97 \\
58.94\end{array}$ & $\begin{array}{c}3.76 \\
20.62 \\
3.23 \\
18.01 \\
17.92 \\
1706 \\
17.43\end{array}$ & $\begin{array}{c}4.89 \\
5.76 \\
1.03 \\
2.75 \\
18.51 \\
1897 \\
23.63\end{array}$ & $\begin{array}{c}\text { sand } \\
\text { sandy loam } \\
\text { sand } \\
\text { sandy loam } \\
\text { sandy loam } \\
\text { sandy loam } \\
\text { sandy loam }\end{array}$ & $\begin{array}{c}1.10 \\
1.22 \\
- \\
- \\
0.93 \\
0.93 \\
0.93\end{array}$ \\
\hline BM3 & $\begin{array}{l}\text { A } \\
\text { E } \\
\text { Bt1 } \\
\text { Bt2 } \\
\text { Bt3 } \\
\end{array}$ & $\begin{array}{l}0-8 \\
8-26 \\
26-46 \\
46-90 \\
90- \\
\end{array}$ & $\begin{array}{c}23.15 \\
4.74 \\
3.48 \\
1.14 \\
1.03 \\
\end{array}$ & $\begin{array}{l}26.84 \\
38.11 \\
24.61 \\
12.37 \\
10.69 \\
\end{array}$ & $\begin{array}{l}50.01 \\
57.15 \\
71.91 \\
86.49 \\
88.28 \\
\end{array}$ & $\begin{array}{l}\text { clay } \\
\text { clay } \\
\text { clay } \\
\text { clay } \\
\text { clay }\end{array}$ & $\begin{array}{l}1.08 \\
0.96 \\
0.94 \\
1.01 \\
1.02 \\
\end{array}$ \\
\hline
\end{tabular}

Pedon BM3 (Reddish Brown Latosols). The soil has an umbric epipedon and an argillic subsurface horizon. The $\mathrm{NH}_{4} \mathrm{Oac} \mathrm{CEC} \mathrm{pH} 7$ is $>16$ me $/ 100 \mathrm{~g}$ clay or the apparent CEC $>12 \mathrm{me} / 100 \mathrm{~g}$ clay. The base saturation of the argillic horizon is lower than $35 \%$. The texture is clay throughout. The clay minerals are dominated by halloysite. This profile is included in Humic Hapludults, clay, isohyperthermic, halloysitic (Soil Survey Staff, 1996), and Humic A/isol (FAO/NNESCO, 1988).

The morphological, physical and chemical characteristics described above suggest that three pedons of the studied soils have different development. Pedon BM1 is Typic Udipsamment, BM2 is Taptho Hapludandic Typic Troporthent, and BM3 is Humic Hapludult. This different stages of development is mostly caused by different relative ages of the parent materials, besides that the elevation difference also plays a roll. As mentioned earlier, the parent material of pedon BM1 is the youngest and that of BM3 is the oldest; hence pedon BM3 has a stronger development than the others and pedon BM1 has the weakest.

Comparison of pedons $B M 3$ and $B M 2$ shows that below $500 \mathrm{~m}$ asl (BM3) no andic properties are present, while above $500 \mathrm{~m}$ asl (BM2) the andic properties are well developed. This is probably due to the clearly temperature influence at both elevations with causes difference in organic matter accumulation in both profiles.

Pedon BM1 has no profile development but since enough water is available the farmers eagerly to transform this sandy soil into paddy rice field. This seems an appropriate decision, because the chemical analysis showed that the available-P and available basic cations in this soil are high. However, they have to add nitrogen fertiliser because nitrogen content of this soils is very low.

In the older classification system is pedon BM3 classified as Latosol. According to Mohr, et al. (1972) Latosols are included in Oxisols without plinthite. Macro and micro morphological analyses show that this pedon seems to be an Oxisol, but mineralogical and chemical analyses show that the weatherable minerals and also the CEC $\mathrm{NH}_{4} \mathrm{OAC} \mathrm{pH} 7$ of clay are still too high for the oxic horizon requirement. Hence, pedon BM3 is classified as Ultisol (Humic Hapludult).

\section{CONCLUSIONS}

The morphological, physical and chemical characteristics of three pedons developed on the volcanic materials of Mt. Galunggung show that these three pedons have different profile developments. The pedon BM1, BM2 and BM3 have no development, medium development and strong development respectively. This different stages of development is mostly caused by different relative ages of the parent materials, and the elevation difference.

According to the Soil Taxonomy (Soil Survey Staff, 1996) pedon BM1, BM2 and BM3 are classified as Typic Udipsamment, Taptho Hapludandic Typic Troporthent, and Humic 
Hapludult; and according to FAO/UNESCO (1988) these pedons are classified as Eutric Regosols, Eutric Regosol, and Humic Alisol respectively.

High available-P of the BM1 which developed on the most recent extrusive volcanic materials are a result of weathering of volcanic glass which probably contains abundant microcrystals of apatite.

\section{REFERENCES}

Bronto, S. 1982. Geologi Gunung Galunggung. PIT XI, Ikatan Ahli Geologi Indonesia, Jakarta.

De Coninck, F. 1990. Regional Pedology part II. ITC, Gent.

Dudal, R. and M. Soepraptohardjo. 1957. Soil classification in Indonesia. Contr. Gen. Agric. Res. Stn. Bogor. 148:1-23

Escher. B. G. 1920. l'Eruption du Goenoeng Galunggung en Julliet 1918. Natuurk. Tijdscur. Nederl. Ind., V 81, p39-40.

FAO/UNESCO. 1974. Soil map of the world, scale 1:5000 000. Vol. I. Unesco, Paris $59 \mathrm{p}$

FAO/UNESCO. 1988. Soil map of the world, revised legend. World soil resources report 60. FAO of the United Nation, Rome. 118p.

Hardjosusastro, R., H. Suyanto dan A.M. Satari. 1983. Andosol dari daerah Sukamantri, Kabupaten Bogor. Pembr. Pen. Tanah dan Pupuk No. 2. Pusat Penelitian Tanah, Bogor.

Leamy, M. L. 1984. Andisol of the world. In Internacional de Suilos Volcanicos. Univ. de La Laguna, Serie Informes. No. 13, p 164-192.
Mohr, E. C. J.; F. A. van Baren and J. van Schuylenborgh. 1972. Tropical soil: A Comprehensive study of their genesis. $3^{\text {rd }}$ ed., Mouton-Ichtiar Baruvan Houve, The Hague-Paris-Djakarta, 480p.

Mulyanto, B. 1990. Some genetic characteristics of the soils on volcanic ash from West Java, Indonesia. Msc Thesis. ITC-RUG. 85p

Prinz M., G. Harlow, and J. Peters. 1978. Rock and minerals. Simon and Shusters Pub., New York. 606p.

Pusat Penelitian Tanah. 1976. Peta Tanah Bagan Indonesia, Skala 1:2.5000. Pusat Penelitian Tanah, Bogor.

Soil Conservation Service. 1984. Procedure for collecting samples and methods of analysis for soil survey; Report no 1. Revised edition, U.S. Dept. Agric., 68p.

Soil Survey Staff. 1996. Key to soil taxonomy. Seventh Edition. USDA. Washington. 644p.

Sutanto, R. 1988. Mineralogy, charge properties and classification of soil on volcanic materials and limestone in Central Java (Indonesia). Ph.D. Desertation, ITC-RUG, Gent.233p.

Tan, K. H. 1959. Klasifikasi tubuh tanah hitam di daerah humid Indonesia. Tehn. Pertan. VII (5): 217-222p.

Tan, K. H. and J. van Schuylenborgh. 1959. On the classification and genesis of soil derived from andesitic volcanic material under a Monsoon climate. Netherl. J. Agric. Sci. 7:41-45.

Tan, K. H., 1965. The Andosols in Indonesia. Soil Sci. 99 (6): 375-378.

Tan, K. H., 1972. Principles of soil chemistry. Macel Dekker Inc., New York. 606p 
Table 3. Chemical Analytical Data

\begin{tabular}{|c|c|c|c|c|c|c|c|c|c|c|c|c|c|c|c|c|c|}
\hline \multirow[b]{2}{*}{ Ped } & \multirow[b]{2}{*}{ Hor } & \multirow[b]{2}{*}{ Depth } & \multicolumn{2}{|c|}{$\mathrm{pH}$} & \multirow{2}{*}{$\begin{array}{c}\text { Org. } \\
\text { Total } \\
\% \\
\end{array}$} & \multirow{2}{*}{$\begin{array}{c}\mathrm{N} \\
\text { Total } \\
\% \\
\end{array}$} & \multirow[t]{2}{*}{$\mathbf{C} / \mathbf{N}$} & \multirow[t]{2}{*}{$\overline{A v-P}$} & \multirow{2}{*}{$\begin{array}{l}\text { Exch } \\
\text { acid }\end{array}$} & \multicolumn{5}{|c|}{ Exchangeable Cations } & \multicolumn{2}{|c|}{$\overline{\mathrm{CEC}}$} & \multirow{2}{*}{$\begin{array}{c}\text { Base } \\
\text { Sat. } \\
\%\end{array}$} \\
\hline & & & $\mathrm{H} 2 \mathrm{O}$ & $\mathrm{KCl}$ & & & & & & $\mathrm{Ca}$ & $\mathbf{M g}$ & K & $\mathrm{Na}$ & sum & $\begin{array}{l}\text { NH4 } \\
\text { OAc }\end{array}$ & sum & \\
\hline \multirow[t]{4}{*}{ BM1 } & I & $0-45$ & 4.20 & 3.60 & 0.11 & 0.02 & 5.50 & 5.20 & 0.95 & 11.83 & 3.92 & 0.25 & 1.05 & 17.05 & 5.30 & 18.00 & 100 \\
\hline & II & $45-85$ & 4.80 & 4.10 & 0.08 & 0.02 & 4.00 & 5.00 & 0.38 & 13.56 & 3.75 & 0.36 & 1.00 & 18.67 & 6.80 & 19.05 & 100 \\
\hline & III & $85-120$ & 5.60 & 4.80 & 0.15 & 0.02 & 7.50 & 6.30 & 0.07 & 11.88 & 3.49 & 0.33 & 0.88 & 16.58 & 6.50 & 16.65 & 100 \\
\hline & IV & $120-$ & 7.10 & 6.00 & 0.88 & 0.03 & 29.33 & 9.20 & 0.07 & 12.12 & 3.49 & 0.33 & 0.85 & 16.79 & 7.50 & 16.86 & 100 \\
\hline \multirow[t]{7}{*}{ BM2 } & I & $0-20$ & 6.50 & 5.20 & 0.27 & 0.02 & 13.50 & 1.10 & 0.07 & 4.13 & 1.09 & 0.13 & 0.12 & 5.47 & 6.20 & 5.54 & 88.23 \\
\hline & II & $20-28$ & 5.80 & 4.50 & 0.19 & 0.02 & 9.50 & 0.30 & 0.53 & 7.02 & 1.70 & 0.30 & 0.24 & 9.26 & 11.80 & 9.79 & 78.47 \\
\hline & III & $28-33$ & 6.20 & 4.20 & 0.15 & 0.02 & 7.50 & 9.20 & 0.23 & 1.73 & 0.17 & 0.04 & 0.05 & 1.99 & 5.60 & 2.22 & 35.54 \\
\hline & IV & $33-38$ & 5.30 & 4.00 & 0.23 & 0.02 & 11.50 & 0.40 & 2.91 & 7.74 & 1.31 & 0.30 & 0.23 & 9.58 & 15.20 & 12.49 & 63.03 \\
\hline & VA & $38-65$ & 5.50 & 4.60 & 3.52 & 0.26 & 13.54 & ns & 0.68 & 0.80 & 0.15 & 0.11 & 0.12 & 1.18 & 26.73 & 1.86 & 4.41 \\
\hline & $\mathrm{VAB}$ & $65-90$ & 6.00 & 4.70 & 3.29 & 0.27 & 12.19 & ns & 0.35 & 1.11 & 0.15 & 0.12 & 0.12 & 1.50 & 30.93 & 1.85 & 4.85 \\
\hline & VA & $90-130$ & 5.90 & 4.90 & 3.75 & 0.27 & 13.89 & ns & 0.15 & 4.26 & 0.20 & 0.07 & 0.20 & 4.73 & 32.30 & 4.88 & 14.64 \\
\hline \multirow[t]{5}{*}{ BM3 } & A & $0-8$ & 5.70 & 4.40 & 2.29 & 0.14 & 16.36 & ns & 0.38 & 7.35 & 2.27 & 0.27 & 0.47 & 10.36 & 22.84 & 10.74 & 45.36 \\
\hline & $\mathrm{E}$ & $8-26$ & 5.20 & 3.90 & 1.36 & 0.11 & 12.36 & 0.20 & 0.98 & 5.44 & 2.15 & 0.16 & 0.34 & 8.09 & 26.96 & 9.07 & 30.01 \\
\hline & Btl & $26-46$ & 5.00 & 3.80 & 1.53 & 0.12 & 12.75 & 0.20 & 1.14 & 4.75 & 2.08 & 0.12 & 0.34 & 7.28 & 25.84 & 8.42 & 28.17 \\
\hline & Bt2 & $46-90$ & 5.00 & 3.70 & 0.48 & 0.05 & 9.60 & ns & 1.29 & 5.04 & 2.11 & 0.07 & 1.12 & 8.34 & 24.15 & 9.64 & 34.54 \\
\hline & $\mathrm{Bt} 3$ & $90-$ & 5.30 & 3.90 & 0.25 & 0.04 & 6.25 & ns & 0.84 & 5.42 & 3.40 & 0.06 & 1.16 & 10.04 & 24.43 & 11.27 & 41.10 \\
\hline
\end{tabular}

